University of Nebraska - Lincoln

DigitalCommons@University of Nebraska - Lincoln

Papers in Natural Resources

Natural Resources, School of

2019

National Survey of Geoscience Teaching Practices 2016: Current Trends in Geoscience Instruction of Scientific Modeling and Systems Thinking

Diane Lally

University of Nebraska - Lincoln, dethom00@gmail.com

Cory T. Forbes

University of Nebraska-Lincoln, cforbes3@unl.edu

Karen S. McNeal

Auburn University

Nicholas A. Soltis

Auburn University

Follow this and additional works at: https://digitalcommons.unl.edu/natrespapers

Part of the Natural Resources and Conservation Commons, Natural Resources Management and Policy Commons, and the Other Environmental Sciences Commons

Lally, Diane; Forbes, Cory T.; McNeal, Karen S.; and Soltis, Nicholas A., "National Survey of Geoscience Teaching Practices 2016: Current Trends in Geoscience Instruction of Scientific Modeling and Systems Thinking" (2019). Papers in Natural Resources. 963. https://digitalcommons.unl.edu/natrespapers/963

This Article is brought to you for free and open access by the Natural Resources, School of at DigitalCommons@University of Nebraska - Lincoln. It has been accepted for inclusion in Papers in Natural Resources by an authorized administrator of DigitalCommons@University of Nebraska - Lincoln. 


\title{
Journal of Geoscience Education
}

\section{National Geoscience Faculty Survey 2016: Prevalence of systems thinking and scientific modeling learning opportunities}

\author{
Diane Lally, Cory T. Forbes, Karen S. McNeal \& Nicholas A. Soltis
}

To cite this article: Diane Lally, Cory T. Forbes, Karen S. McNeal \& Nicholas A. Soltis (2019): National Geoscience Faculty Survey 2016: Prevalence of systems thinking and scientific modeling learning opportunities, Journal of Geoscience Education, DOI: 10.1080/10899995.2019.1565286

To link to this article: https://doi.org/10.1080/10899995.2019.1565286

Published online: 11 Apr 2019.

Submit your article to this journal $₫$

View Crossmark data $־$ 


\title{
National Geoscience Faculty Survey 2016: Prevalence of systems thinking and scientific modeling learning opportunities
}

\author{
Diane Lally ${ }^{\mathrm{a}}$, Cory T. Forbes ${ }^{\mathrm{a}}$ (D), Karen S. McNeal ${ }^{\mathrm{b}}$ and Nicholas A. Soltis ${ }^{\mathrm{b}}$

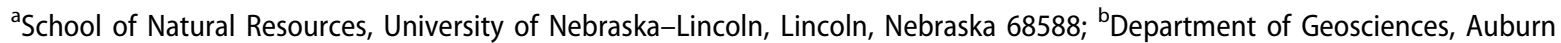 \\ University, Auburn, Alabama 36849
}

\begin{abstract}
Scientific modeling and systems thinking (SMST) is central to the geosciences, yet few studies have documented how and to what extent undergraduate geoscience courses emphasize SMST, as well as factors that might help explain or predict these trends. Here, we present research based on data $(n=2056)$ from the most recent $(2016)$ administration of the National Geoscience Faculty Survey, administered to a national sample of postsecondary geoscience instructors in the United States. We investigated instructor- and course-related variables as they relate to a set of 9 survey items that serve as a composite measure for SMST. Significant variation was observed in reported frequencies of individual SMST practices in undergraduate geoscience courses. The highest levels of reported SMST were associated with faculty from atmospheric and environmental sciences, those who emphasized research-based, studentcentered pedagogical practices, those who recently made changes to both course content and teaching methods, and those who reported high levels of engagement in instructional improvement activities (workshops, presentations, seminars). Reported SMST practices were similar for faculty identifying as geoscientists and geoscience education researchers, and both were significantly higher than for teaching-focused faculty who do not conduct research. A linear regression model including variables found to be significant in the analyses was able to predict $17 \%$ of the overall variance in reported SMST practices. These findings illustrate the importance of instructors' disciplinary orientation and active engagement in instructional innovation as related to SMST, and provide important points of impact for enhancing SMST in undergraduate geoscience courses through course design and faculty development. However, the relatively modest predictive power of the regression model indicates there are many other factors influencing SMST that warrant future research.
\end{abstract}

\section{ARTICLE HISTORY}

Received 26 August 2018 Revised 19 October 2018 and 11 December 2018 Accepted 02 January 2019 Published online 10 April 2019

\section{KEYWORDS}

Geoscience education; systems thinking; scientific modeling; undergraduate

\section{Introduction}

Worldwide, there continues to be a growing emphasis on effective undergraduate teaching and learning in science, technology, engineering, and mathematics (STEM). Increasingly, STEM policymakers, faculty, industry leaders, and university administrators are recognizing the importance of well-developed and effective undergraduate STEM programs in meeting the needs of the STEM workforce and cultivating scientifically literate citizens. Students in postsecondary institutions should learn the skills and concepts necessary to be competitive in the job market and productive members of society. To be effective in future endeavors, students need to be able to analyze information, problem solve in the context of ill-defined socio-environmental challenges, and integrate multidisciplinary concepts in their reasoning about Earth systems (Mosher et al., 2014). These needs suggest undergraduate geoscience education is in an important position to positively impact society.

A central element of effective undergraduate geoscience teaching and learning involves scientific modeling and systems thinking (SMST). As Arnold and Wade (2015, p. 671) noted, "Systems thinking is a set of synergistic analytic skills used to improve the capability of identifying and understanding systems, predicting their behaviors, and devising modifications to them in order to produce desired effects. These skills work together as a system." Systems thinking in geoscience education is beneficial because students learn to think about a system from multiple viewpoints (Danish, Saleh, Andrade, \& Bryan, 2017). As students develop geoscience understanding, the complexity of

CONTACT Cory T. Forbes cory.forbes@unl.edu $\Theta$ School of Natural Resources, University of Nebraska-Lincoln, Hardin Hall, 3310 Holdrege Street, Lincoln, NE 68588, USA.

Color versions of one or more of the figures in the article can be found online at www.tandfonline.com/ujge.

(C) 2019 National Association of Geoscience Teachers 
these systems can be explored with increasing depth, demonstrating the interconnectedness of systems and spheres of Earth. Scientific modeling is a critical component of systems thinking that contributes to holistic understanding in the geosciences. It involves the use of historical data and future, empirically based predictions for systems-related phenomena, each of which temporally examines system interactions (Kastens et al., 2009; Troy, Konar, Srinivasan, \& Thompson, 2015), often with support from technological tools. SMST approaches help to support students' development of robust mental models of how Earth systems interact.

However, little is known about how SMST practices are taught in undergraduate geoscience courses. There is still a need to know more about SMST-specifically, how and why it is implemented by instructors, how often they include it in their courses, and what types of SMST practices are most common in undergraduate classrooms. Although studies of individual courses or instructional interventions may provide empirical insights into SMST in geoscience education (Forbes et al., 2018; Gunn, Mohtar, \& Engel, 2002; Williams, Lansey, \& Washburne, 2009), few efforts have attempted to document where, when, why, and how SMST elements are being emphasized in undergraduate geoscience courses, as well as factors that can help explain or predict these trends. The purpose of the present study, in which we analyze survey data from a national sample of geoscience faculty in the United States, is to begin to address these questions. Specifically, we ask the following research questions:

1. To what extent do geoscience instructors report engaging students in scientific modeling and systems thinking?

2. What instructor- and course-level factors help predict and explain the extent to which geoscience instructors report engaging students in scientific modeling and systems thinking?

\section{Undergraduate teaching and learning in the geosciences}

Educational experiences that prepare future problem solvers require affording all students opportunities to learn how to think scientifically, particularly in undergraduate classrooms (National Research Council [NRC], 2012), including the geosciences. Over the last half-century, geoscience education has undergone significant change in its purpose and organization (Libarkin, 2006; Tewksbury et al., 2013). Historically, geoscience education was designed primarily to develop future geoscientists. However, given the inherent opportunities it affords students to engage in evidence-based reasoning about Earth systems (Somerville \& Bishop, 1997; Tewksbury et al., 2013), geoscience education also plays an important role in helping students develop scientific literacy. With increasing emphasis on teaching and learning in the geosciences and the development of geoscience education research (GER) as a field of inquiry in recent decades, geoscientists and geoscience educators are more strongly positioned than ever to efficiently and effectively evaluate and assess the efficacy of teaching and learning practices on these two parallel outcomes of geoscience education.

Beginning in the early 2000s, purposeful efforts have been made to define target outcomes of geoscience education. Partnerships between various organizations-including the National Science Foundation, the National Oceanic and Atmospheric Administration, the American Association for the Advancement of Science, the Earth Science Literacy Initiative, and the U.S. Department of Energy, among others-have contributed to the development of standards, principles, and frameworks for general Earth science literacy (Earth Science Literacy Initiative, 2010), climate literacy (U.S. Global Change Research Program [U.S. GCRP], 2009), and energy literacy (U.S. Department of Energy [U.S. DoE], 2012). In each of these documents, SMST is prioritized as a core experience and outcome for learners at all levels, including undergraduate geoscience education. In the Earth Science Literacy Principles (Earth Science Literacy Initiative, 2010), for example, SMST is central to the definition of Earth science literacy, in which "an Earth science-literate person understands fundamental concepts of Earth's many systems" (Earth Science Literacy Initiative, 2010, p. 2). They also emphasize the need for students to "construct and refine computer models that represent the climate system" (U.S. GCRP, 2009) and "think in terms of energy systems" (U.S. DoE, 2012). The development of these documents instantiates and enhances the importance placed on SMST within the context of geoscience education.

The landscape of geoscience education is changing in parallel with broader undergraduate STEM education reform efforts in the United States (NRC, 2012). Not only are geoscientists in academia expected to do impactful scientific research but, in order to remain competitive and relevant, they must also engage in innovative instruction (Somerville \& Bishop, 1997). 
However, educators need help finding and learning to use best practices in geoscience education. As such, geoscience instructors are increasingly participating in professional development opportunities to develop new skills that enhance geoscience education (Manduca et al., 2017). However, the reach and impact of these opportunities is not evenly distributed. For a variety of reasons, some instructors engage in these opportunities with greater frequency than others (Libarkin \& Anderson, 2005; Macdonald, Manduca, Mogk, \& Tewksbury, 2005). Despite the literature and resources available to geoscience instructors, more work is needed to understand which instructional strategies are most beneficial to students. Understanding the use of SMST practices by instructors and the associated impacts on student learning is one area that warrants further study.

\section{Scientific modeling and systems thinking}

Scientific modeling and systems thinking are two interrelated practices and "habits of mind" central to the geosciences and geoscience education. Systems thinking is the study of the interplay between the subsystems comprising an overall system (Bawden, Macadam, Packham, \& Valentine, 1984; Scherer, Holder, \& Herbert, 2017). Systems thinking involves the explicit description of the system as a whole and the links between its constituent parts and processes (Arnold \& Wade, 2015). Processes occur simultaneously through both large- and small-scale interactions and feedbacks (Assaraf \& Orion, 2005). Learning how to think about the interactions between systems, the far-reaching effects of a system, and the dynamic nature of systems are all ways to demonstrate scientific literacy. Both are core components of the work of geoscientists and critical outcomes for undergraduate STEM education, particularly in the geosciences.

A primary mechanism to investigate systems is through models. Scientific models are inherently simplified versions of complex systems. Modeling is a way in which students can both learn to make predictions based on evidence and communicate their understanding of a phenomenon (Baumfalk et al., in press; Schwarz, et al. 2009). Contemporary science, and particularly geoscience, is heavily reliant on computer-based models to support research on complex systems, and overlapping components of socioscientific issues makes modeling more difficult (Troy, Konar, Srinivasan, \& Thompson, 2015). However, models do offer the opportunity to hypothesize and experiment with varying outcomes of a model in the pursuit of a suite of potential solutions. Research suggests there are a number of ways to help students succeed in the use of computer-based models. Students have reported the presence of an instructor as beneficial even if they are working in groups on a modeling problem (Zigic \& Lemckert, 2007). Students have expressed interest in computer-based models and reported that they add to understanding of complex processes, describing them as useful; they also have reported that participation in class and the skill of the instructor are key components to computer-based model learning (Williams, Lansey, \& Washburne, 2009). Instructors have an important role to play in developing student modeling skills, despite students' seeming familiar with technology overall. Learning SMST practices is a valuable way to help students transition from learning facts to generating new ideas and solutions to problems.

There are several concrete ways instructors can help students develop systems thinking skills. Spending time discussing not only the mechanisms and patterns surrounding components but also the scale of certain features helps students make systems thinking connections (Hmelo-Silver et al., 2017; McNeal, Miller, \& Herbert, 2008). Sometimes it is difficult for students to conceptualize how all of the components of a system might be connected or the ways in which seemingly disparate components are connected, including in the geosciences (Macdonald, Manduca, Mogk, \& Tewksbury, 2005). The more instructors engage students in discussion about areas of difficulty, the more detail they will be able to include in their systems thinking models. Not every cause and effect will have the same impact on a system, so instructors explicitly teaching students to evaluate the size of the impact and the range of likely effects of an interaction can help increase precision in students' model development. Instructors can provide opportunities for discussing and learning how mechanisms or processes can be transferred from one component to another component within a system; this type of thinking will increase the complexity and accuracy of student systems models (Hmelo-Silver et al., 2017). The ways instructors can help students increase SMST skills are known, but gaps still exist in the "how" and "to what extent" this set of important practices is emphasized in undergraduate geoscience courses.

\section{Methods}

\section{Survey instrument}

This study is based on data from the 2016 administration of the National Geoscience Faculty Survey. 
The survey was designed by a research team involving leadership from the National Association of Geoscience Teachers (NAGT) along with three National Science Foundation (NSF)-funded professional development projects (On the Cutting Edge, InTeGrate, and SAGE 2YC). This survey-as well as earlier versions administered in 2004, 2009, and 2012-is publically available. Data derived from the first three distributions of the Geoscience Faculty Survey were reported by Macdonald and colleagues (2005) and Manduca and colleagues (2017). The 2016 survey, which provided information about undergraduate geoscience course instructors and course characteristics, had open response and Likert-style questions which probe instructor teaching and learning practices from general strategies to specific actions, as well as demographic info about respondents. The survey consisted of 209 questions, with a median completion time of 14.4 minutes. Respondents answered questions about their (a) disciplinary focus, teaching background, and institution; (b) introductory level course teaching strategies; (c) major teaching; (d) learning new teaching methods, active learning strategies included, and course changes; (e) communication within the geosciences community and their reasons for attending teaching workshops; and (f) use of online resources, articles published, and conference presentations. Respondents provided information about the year in which they received their terminal degree, how many years they had been teaching at the postsecondary level, their position title, and how many courses they taught. In terms of their course, they were asked about how many students the course served, its format (i.e., face-to-face vs. online), if they had instructional support in the form of teaching assistants, and if there was a lab section associated with the course.

The focus of this study is on opportunities in undergraduate geoscience courses for students to engage in SMST practices. The survey included a set of nine items in which respondents were asked to identify one or more sets of practices in which they engaged students in their courses through "yes" or "no" responses. Practices included (a) discussion of changes in a system, (b) feedback loop analysis, (c) system mapping, (d) exploration of systems with computer models, (e) building predictive models, (f) discussions of implications and predictions, (g) discussions of scale and interactions, (h) distinguishing current processes and results of history, and (i) description of system parts and relationships. These nine items serve as the measure for the outcome variable of interest in this study-SMST.

\section{Sampling}

The 2016 survey was administered to a set of respondents based on a national sample of geoscience faculty. The target population was identified from publicly available records and membership lists associated with relevant U.S. geoscience departments at two- and four-year institutions (community colleges, liberal arts colleges, and research-intensive universities), professional communities, geoscience education listservs maintained by SERC, and previous and current geoscience education projects serving postsecondary geoscience faculty, including On the Cutting Edge $(n=10,910)$. Full-time faculty, adjunct faculty, instructors, and lecturers were eligible for surveying. Individuals included in the sample met the requirements of actively teaching postsecondary geoscience courses and having legitimate, functioning email addresses. From these resources, a sample of 9,596 geoscience faculty members were identified as eligible. The participants included members of the American Geological Institute, SERC Cutting Edge participants, Geosciences Two-Year College list, SAGE Two-Year College List, SERC Early Career List, and meteorology faculty.

\section{Data collection and analysis}

From this sample, 200 randomly selected individuals were contacted via email and invited to participate in a pilot administration of the 2016 survey, of which 33 individuals responded. The results from the pilot survey were used to modify wording of some of the survey items to be sent to the remaining 10,910 individuals. After the pilot, the remaining individuals in the sample were invited to complete the survey. Al individuals received email copies of the survey, were contacted up to four times to complete the survey, and those completing the survey did so electronically. Of these potential participants, 27.3\% $(n=2615)$ of the 9,596 eligible individuals answered one or more questions on the survey. The findings reported here are based on the sample of respondents who completed all items used as data for this study $(n=2056)$, a response rate of $21.4 \%$. Respondents were primarily from research/doctoral and master's institutions. However, the response rate was lowest among research/doctoral institutions and highest among all other institution types. Fewer individuals in the 
Table 1. Survey items and independent variables associated with reported scientific modeling and systems thinking course elements.

\begin{tabular}{|c|c|}
\hline Variable & Description \\
\hline 20_COMP & SMST course elements \\
\hline S16_1 & Geoscience subdiscipline of faculty respondent \\
\hline S16_25_COMP & Number of changes made to course content in past two years \\
\hline S16_27_COMP & Number of changes made to teaching methods in past two years \\
\hline PRESENENTRESEARCHR & Number of meetings presented scientific research within the past two years \\
\hline NUMPUBLISHR & Number of articles about research published in the past two years \\
\hline TALKCONTENT & $\begin{array}{l}\text { Frequency of conversation with colleagues about course content over the } \\
\text { past two years }\end{array}$ \\
\hline ATTENDTEACHTALKSR_2 & $\begin{array}{l}\text { Number of talks on teaching methods, other topics related to science educa- } \\
\text { tion, or geoscience education attended in the past two years at profes- } \\
\text { sional meetings, on campus, or at other venues }\end{array}$ \\
\hline ATTENDWRKSHPR & $\begin{array}{l}\text { Number of workshops related to improving teaching attended in the past } \\
\text { two years }\end{array}$ \\
\hline PRESENTTEACH & $\begin{array}{l}\text { Number of presentations of research on teaching methods or student learn- } \\
\text { ing at meetings within the past two years }\end{array}$ \\
\hline NUMARTICLES & $\begin{array}{l}\text { Number of articles published about educational topics within the past } \\
\text { two years }\end{array}$ \\
\hline TRADLECb & Frequency of use of traditional lecture \\
\hline LECDEMOb & Frequency of use of demonstration \\
\hline INDIVQUESTb & Frequency of use of individual student questions \\
\hline ALLQUESTb & Frequency of use of asking whole-class questions \\
\hline SMALLGRPDISb & Frequency of use of small-group discussion \\
\hline WHOLEGRPDISb & Frequency of use of whole-class discussion \\
\hline INCLASSb & Frequency of use of in-class assignments \\
\hline
\end{tabular}

sample population described their disciplinary focus as oceanography or atmospheric science than geology, which accounted for $81 \%$ of the sample. Demographic characteristics of respondents are presented in Appendix A.

The survey dataset was compiled and imported into SPSS software for statistical analyses. We used inferential statistical methods to evaluate relationships between the outcome of interest-reported SMST practices in undergraduate geoscience courses-and a variety of other faculty- and course-level variables, as reported by respondents in the survey. Standard parametric tests rely on the underlying assumptions of normal distribution and equal variances (or standard deviation) for the variables subject to analysis. Here, the distribution of scores for our outcome variable of interest (SMST) exhibited both skewness (.16) and kurtosis (-.62) values falling between -1 and 1 , indicating scores were normally distributed. Therefore, the utilized correlation, $t$-tests, and ANOVA to assess relationships between variables from the survey data.

Pearson correlations were conducted to assess the strength and direction of relationships between two variables from the same individuals for analyses within groups. Reported correlation $(r)$ values fall between -1 and 1 and indicate the extent to which two variables are linearly related within a single sample or group. Additionally, $t$-tests and ANOVAs (with Tukey's post hoc tests) were conducted to compare mean SMST scores and subscores between groups of survey respondents. The $t$-test and one-way analysis of variance (ANOVA) are appropriate tests for comparing mean of variables involving two or more groups. A $t$-test is used to assess whether the means of two groups are statistically different from each other. The $t$-statistic is the ratio of mean difference and standard errors of the mean difference $t$-test. For a comparison of more than two group means, the ANOVA is the appropriate method of analysis. The $F$ ratio is the ratio of mean square values in which the larger the $F$ ratio, the larger the difference in variation between the groups tested for a given variable. Tukey's post hoc tests are then run on individual pairings of groups used in the ANOVA to establish statistically significant differences between the individual groups. Through these analyses, we observed that most instructor-level factors and course-level factors identified in the survey were not related to the SMST course elements reported by respondents. However, instructor-level and course-level factors that exhibited statistically-significant relationships with the outcome of interest-SMST course elements-are summarized in Table 1.

Based on these analyses, a multiple regression model was constructed to investigate the extent to which instructor- and course-level variables identified as significant through $t$-tests, ANOVAs, and correlations predict reported SMST elements in undergraduate geoscience courses. A multiple linear regression is used to model the relationship between two or more independent, or predictor, variables and a single, dependent variable by fitting a linear equation to 
Table 2. Frequencies of reported scientific modeling and systems thinking course elements.

\begin{tabular}{llrr}
\hline Item & Are there elements in your course that enable your students to: & Percentage (\%) & SD \\
\hline 1 & Discuss a change that has multiple effects throughout a system & 54 & .50 \\
2 & Analyze feedback loops & 34 & .47 \\
3 & Make systems visible through causal maps & 26 & .44 \\
4 & Explore systems behavior using computer models & 20 & .40 \\
5 & Build predictive models & 22 & .41 \\
6 & Discuss relationship between implications and predictions & 42 & .49 \\
7 & Discuss complexity of scale and interactions & 59 & .49 \\
8 & Distinguish outcomes of current processes from results of prior history & 42 & .49 \\
9 & Describe a system in terms of its parts and relationships & 64 & .48 \\
\hline
\end{tabular}

observed data. It provides an $\mathrm{R}^{2}$ value (between 0 and 1 ), which represents the percentage of variance in the dependent variable explained by the predictor variables used in the model. The objective of these analyses is to infer probabilities that statistically significant relationships observed in this population would be predictive of those in the broader population of undergraduate geoscience instructors. Consistent with the purpose of multiple linear regression, these results explain the strength of the relationship between predictor variables and the outcome variable of interest (SMST), as well as how increasing values of predictor variables would help predict increasing SMST in undergraduate geoscience courses. All analyses involved two-tailed tests with significance at the $p<$ .05 level and Cohen's $d$ as the reported measure of effect size. Means $(M)$ and standard deviations $(S D)$ are reported as descriptive statistics for variables of interest.

\section{Results}

\section{Overview of results}

In the sections that follow, we present results from analysis of the survey data to address our research questions. Overall, primary findings are summarized as follow:

- On average, geoscience faculty members reported including fewer than four SMST practices in their undergraduate classes.

- SMST practices are more commonly emphasized in courses for geoscience majors than for nonmajors, but only slightly.

- Faculty from atmospheric science/meteorology, environmental sciences, and hydrology reported emphasizing the most SMST practices, whereas those from geology reported the fewest.

- Faculty who reported being significantly engaged in instructional innovation (course revisions, attuned to research and best practices in geoscience education, and seeking out instructional support) and identify with a community of geoscience educators reported more emphasis on SMST practices than those who did not.

- These variables account for approximately $17 \%$ of the observed variance in reported SMST practices emphasized in undergraduate geoscience courses.

\section{Reported scientific modeling and systems thinking course elements}

In Research Question 1, we asked, "To what extent do geoscience instructors report engaging students in scientific modeling and systems thinking?" To address this question, we analyzed frequencies with which survey respondents reported SMST elements in their undergraduate geoscience courses. Response frequencies for the nine $(n=9)$ survey items that comprised the composite SMST scale are presented in Table 2.

As shown in Table 2, there was variation in how frequently these course elements were reported by survey respondents. The most commonly reported course element was describing a system in terms of its parts and relationships (Item 9), with over $60 \%$ of survey respondents reporting emphasizing this element as a part of their course. At the low end of the continuum, only $20 \%$ survey respondents reporting using computer models to explore systems behavior (Item 4). The frequencies for the remaining items fell somewhere between these two ends of the range of reported SMST practices. Standard deviations for these items ranged between .4 and .5 , with a majority between .45 and .5 .

To generate a single, composite score for our outcome variable of interest-SMST course elements-we summed scores for the nine items in Table 2. This composite SMST score, with a range of 0 to 9, provides an overall measure of reported opportunities for students to engage in SMST in undergraduate geoscience courses. To address reliability and validity of the composite score, or scale, we conducted principal component and Monte Carlo simulations, which confirmed that the nine items represented a single factor. Reliability analyses show this scale to have moderate 


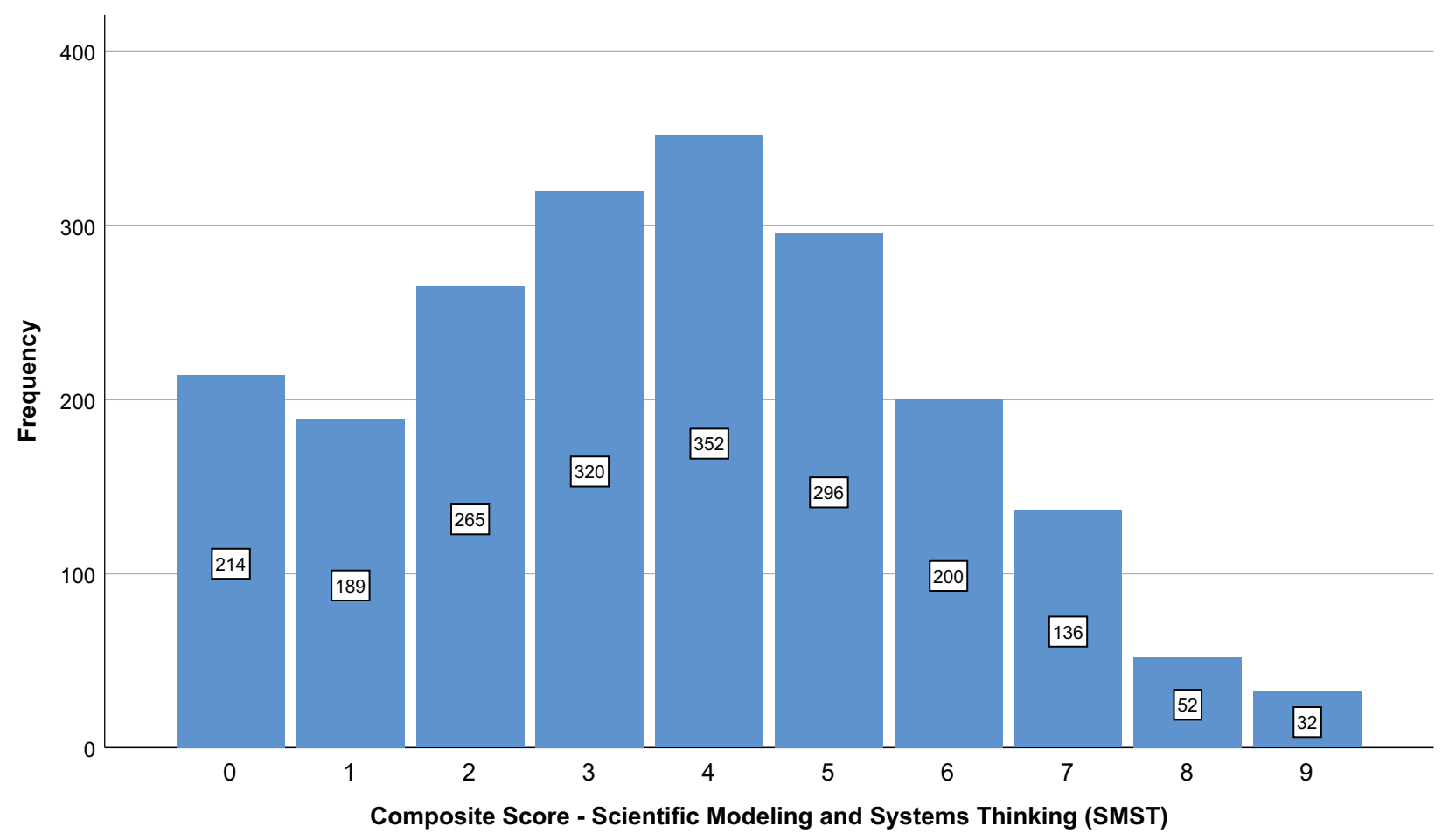

Figure 1. Frequencies of composite score for reported scientific modeling and systems thinking course elements.

Table 3. Correlations between changes to course content, changes to teaching methods, and SMST.

\begin{tabular}{lccc}
\hline Variables & 1 & 2 & 3 \\
\hline 1. Changes to course content & - & & \\
2. Changes to teaching methods & $.45^{* * *}$ & - & \\
3. SMST & $.36^{* * *}$ & $.21^{* * *}$ & - \\
\hline${ }^{*} p<.05 ;{ }^{* *} p<.01{ }^{* * *} p<.001$. & &
\end{tabular}

to high internal consistency (Cronbach's $\alpha=.68$ ). As such, the nine items are treated as a single reliable factor for composite SMST score in the analyses that follow. Overall, survey respondents reported a mean of 3.61 SMST course elements in their classes $(S D=2.22)$. Nearly $50 \%$ of respondents reported three or fewer course elements supporting scientific modeling and systems thinking, whereas only $10 \%$ reported seven or more. A frequency distribution for respondents' composite SMST course elements is shown in Figure 1.

\section{Reported SMST course elements}

In Research Question 2, we asked, "What instructorand course-level factors help predict and explain the extent to which geoscience instructors report engaging students in scientific modeling and systems thinking?" In the sections that follow, we describe instructorand course-level variables for which statistically significant relationships were observed in the 2016 survey.

\section{Course components and SMST}

Respondents were asked whether they had made changes to the content and teaching methods in their courses within the past two years. For those who reported making such changes to either content and/ or teaching methods, they then responded "yes" or "no" to a set of 10 additional items describing types of changes they might have made to course content and teaching methods. Findings from analysis of these survey items suggest that changes made to the content and teaching methods in geoscience courses, as well as the extent of those changes, were positively associated to the opportunities afforded students to engage in SMST in these courses. A higher number of respondents reported making changes to course content and teaching methods than those who did not, meaning a majority of respondents indicated changing aspects of their courses in the recent past. As shown in Table 3, those instructors who reported making more changes to course content also tended to make more changes to their teaching methods. Additionally, for those who reported making these changes, the number of changes made was positively correlated to the use of SMST course elements, for both course content and teaching methods. Overall, the more instructors were actively modifying the content taught in their courses, as well as their approaches to teaching it, the more SMST opportunities they reported for students in their courses, as shown in Table 4 . 
Table 4. Results of $t$-tests and descriptive statistics for SMST by changes to course content and teaching methods.

\begin{tabular}{|c|c|c|c|c|c|c|c|c|c|c|}
\hline \multirow[b]{3}{*}{ Outcome } & \multicolumn{6}{|c|}{ Group } & \multirow[b]{3}{*}{$95 \% \mathrm{Cl}$ for mean difference } & \multirow[b]{3}{*}{$t$} & \multirow[b]{3}{*}{$d f$} & \multirow[b]{3}{*}{$d$} \\
\hline & \multicolumn{3}{|c|}{ Changes } & \multicolumn{3}{|c|}{ No changes } & & & & \\
\hline & $M$ & $S D$ & $n$ & $M$ & $S D$ & $n$ & & & & \\
\hline SMST (course content) & 3.75 & 2.22 & 1585 & 3.13 & 2.14 & 432 & $-.848,-.379$ & $-5.13^{*}$ & 2015 & .28 \\
\hline SMST (teaching methods) & 3.78 & 2.21 & 1128 & 3.42 & 2.21 & 885 & $-.549,-.160$ & $-3.58^{*}$ & 2011 & .16 \\
\hline
\end{tabular}

Table 5. Results of $t$-tests and descriptive statistics for SMST by course audience (geoscience majors or nonmajors).

\begin{tabular}{|c|c|c|c|c|c|c|c|c|c|c|}
\hline \multirow[b]{3}{*}{ Outcome } & \multicolumn{6}{|c|}{ Group } & \multirow[b]{3}{*}{ 95\% Cl for mean difference } & \multirow[b]{3}{*}{$t$} & \multirow[b]{3}{*}{$d f$} & \multirow[b]{3}{*}{$d$} \\
\hline & \multicolumn{3}{|c|}{ Majors } & \multicolumn{3}{|c|}{ Nonmajors } & & & & \\
\hline & M & $S D$ & $n$ & M & $S D$ & $n$ & & & & \\
\hline SMST & 3.73 & 2.25 & 1024 & 3.5 & 2.2 & 1032 & $-.427,-.043$ & $-2.4^{*}$ & 2054 & .1 \\
\hline
\end{tabular}

${ }^{*} p<.001$.

Respondents were asked to identify whether their undergraduate course was an introductory course for students majoring in a geoscience degree program or an introductory course for a broader population of students. Those who completed the survey in respect to an undergraduate course they taught for geoscience majors reported including more SMST elements in their courses than those teaching introductory courses for nonmajors, as shown in Table 5 .

\section{Disciplinary profile and SMST}

In the survey, respondents were asked to characterize their geoscience subdisciplinary orientation into one of the following categories: (a) geology or geophysics, (b) oceanography or marine sciences, (c) atmospheric science or meteorology, (d) geoscience education/science education, or (e) other (please specify). For the other category, respondents could include a brief description of their disciplinary focus within the geosciences. Respondents who selected the other category identified primarily as environmental science, hydrology and hydrogeology, geography, soil science, or geochemistry faculty. Overall, findings suggest respondents from the atmospheric sciences, meteorology, and other self-classified categories (e.g., environmental science, hydrology) reported engaging students in more SMST course elements than did instructors from geology, oceanography, and geoscience education, $F(4,2050)=13.5, p=.009$. Mean SMST scores by subdiscipline are shown in Figure 2. Post hoc comparisons indicated that the mean score for atmospheric science or meteorology had the highest reported number of SMST course elements and was significantly different than the geology or geophysics category, which had the fewest number of SMST course elements. The mean score for other was the second highest and was also significantly different than the geology or geophysics category. The oceanography or marine sciences and geoscience education/ science education did not significantly differ from each other or the other categories. A student in a course taught by an instructor from atmospheric science, meteorology, environmental science, or hydrology would be significantly more likely to experience SMST course components than a student in a geology/geophysics course.

\section{Faculty teaching profile and SMST}

A set of analyses was conducted on survey items and composite variables focused on respondents' overall engagement in activities associated with the improvement of undergraduate instruction. In general, respondents who reported a higher level of engagement in undergraduate geoscience teaching and instructional innovation generally reported more opportunities for students to engage in SMST practices in their courses. These findings suggest that instructors with significant levels of engagement in professional development experiences focused on undergraduate geoscience teaching report more SMST opportunities for students in their courses than do other faculty. For example, respondents were asked two questions about the number of (a) geoscience teaching presentations and (b) workshops they had attended in the past two years: (0) none, (1) one or two, (2) three or four, (3) five of six, (4) seven or eight (5), nine or 10, (6) 11 or more. Respondents who reported attending presentations, $F(6,2003)=$ 4.09, $p<.001$, and workshops, $F(5,1996)=4.77, p<$ .001 , on geoscience teaching methods and/or student learning at a professional conference in the past two years also reported incorporating more SMST elements into their courses than those respondents who had not attended presentations on geoscience teaching 


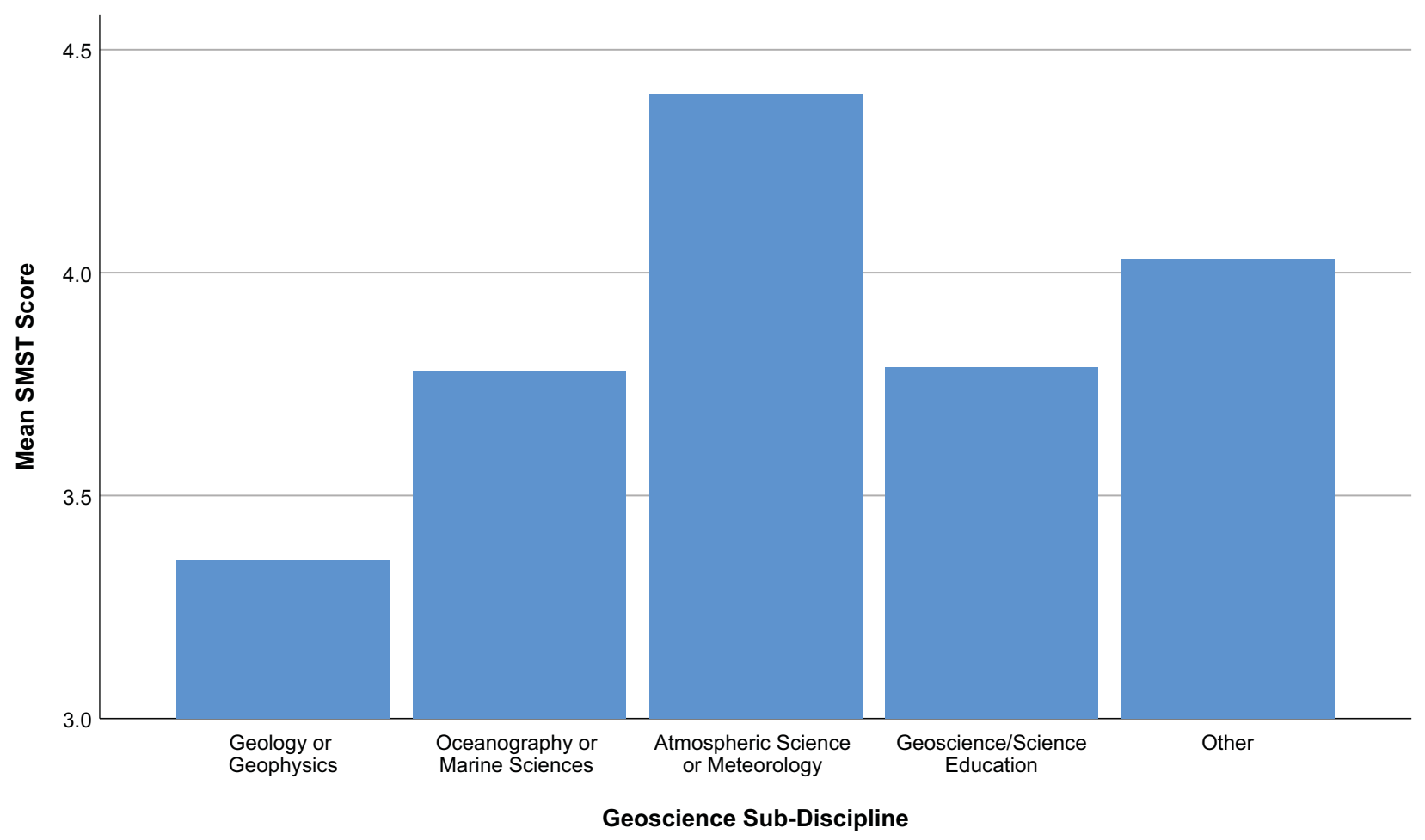

Figure 2. Mean scientific modeling and systems thinking course elements reported by instructors from geoscience subdisciplines.

Table 6. Results of $t$-tests and descriptive statistics for SMST by attendance at presentations of geoscience teaching.

\begin{tabular}{|c|c|c|c|c|c|c|c|c|c|c|}
\hline \multirow[b]{3}{*}{ Outcome } & \multicolumn{6}{|c|}{ Presentations on geoscience teaching } & \multirow[b]{3}{*}{$95 \% \mathrm{Cl}$ for mean difference } & \multirow[b]{3}{*}{$t$} & \multirow[b]{3}{*}{$d f$} & \multirow[b]{3}{*}{$d$} \\
\hline & \multicolumn{3}{|c|}{ Attended } & \multicolumn{3}{|c|}{ Did not attend } & & & & \\
\hline & $M$ & $S D$ & $n$ & $M$ & $S D$ & $n$ & & & & \\
\hline SMST (presentations) & 4.12 & 2.21 & 471 & 3.48 & 2.20 & 1525 & $.409, .863$ & $-5.49^{*}$ & 1994 & .30 \\
\hline SMST (workshops) & 4.10 & 2.20 & 589 & 3.43 & 2.18 & 1420 & $.363, .932$ & $5.12^{*}$ & 2009 & .28 \\
\hline
\end{tabular}

topics (see Table 6). For those respondents who reported attending presentations and/or workshops, there is evidence that attending more was associated with higher reported SMST than only attending a few. Post hoc comparisons indicated that those instructors who attended nine or more presentations on geoscience teaching reported higher implementation of SMST course elements than those who had attended only one or two teaching presentations. Similarly, they show that those respondents who attended nine or more workshops on geoscience teaching reported higher implementation of SMST course elements than those who had attended only one or two teaching workshops.

Finally, respondents were asked how strongly they affiliated with a community of geoscience educators with shared goals, philosophies, and values for geoscience education: (1) not at all, (2) to a little extent, (3) to some extent, or (4) to a great extent. Findings suggest that those geoscience faculty members who identify with a community of geoscience educators to at least a moderate degree report more SMST course elements than those who do not, $F(3,1996)=13.2$, $p<.001$. Post hoc comparisons indicated that respondents who identified with a community of geoscience educators to a great extent reported more SMST course elements than did respondents who reported identifying with a community of geoscience educators to some extent, to a little extent, or not at all. Respondents who reported identifying with a community of geoscience educators to some extent also reported more SMST course elements than did those reporting the lowest two categories. No statistically significant difference was observed between the two groups that reported identifying with a community of geoscience educators to the least extent. The stronger an instructor's sense of identity as part of the geoscience education community, the more SMST course components he or she report in his or her undergraduate geoscience courses. 
In Manduca and colleagues' (2017) article analyzing results of previous administrations of the survey, the following items from Table 3 were used to identify subgroups of faculty based on factor analyses:

1. Number of meetings presented scientific research within the past two years;

2. Number of articles about research published in the past two years;

3. Frequency of conversation with colleagues about course content over the past two years;

4. Number of talks on teaching methods, other topics related to science education, or geoscience education attended in the past two years at professional meetings, on campus, or at other venues;

5. Number of workshops related to improving teaching attended in the past two years;

6. Number of presentations of research on teaching methods or student learning at meetings within the past two years; and

7. Number of articles published about educational topics within the past two years.

They identified three groups of respondents who differed in their teaching and research roles, participation in teaching-related professional development, and self-described instructional identities. These faculty groups (Manduca et al., 2017, pg. 3) were as follow:

1. geoscience education-focused faculty, who reported significant activity related to improving teaching (their own and/or others);

2. geoscience research-focused faculty, who reported significant geoscience research activity; and

3. teaching faculty, who reported lower levels of activity in both geoscience research and activity related to improving teaching.

Consistent with Manduca and colleagues' (2017) previous study, education-focused faculty made up the smallest percentage (18\%) of respondents, whereas teaching faculty were the largest group (43\%), with geoscience research-focused faculty comprising $39 \%$ of respondents in the 2016 survey.

Findings show that reported SMST course elements vary by faculty group, $F(6,2009)=16.5, p<.001$. Post hoc comparisons indicated that teaching faculty reported fewer SMST course elements than both education-focused and geosciences-research-focused faculty. Although education-focused faculty reported slightly more SMST course elements than did geosciences research-focused faculty, this observed difference was not statistically significant. These results indicate that both geoscience education- and geosciences research-focused faculty reported incorporating equivalent SMST opportunities for students in their courses, and both groups do so more than teaching faculty.

Instructional Profiles and SMST. A set of analyses was also conducted on survey items and composite variables focused on respondents' reported teaching practices. In general, respondents who reported greater use of research-based STEM instructional practices (i.e., active learning) as opposed to more traditional teaching methods also reported more opportunities for students to engage in SMST practices in their courses.

Respondents answered a series of items regarding the extent to which they used particular forms of instruction in their classes as (1) never, (2) once, (3) several times, (4) weekly, or (5) every class. Overall, findings suggest that those geoscience instructors who reported using more research-based, student-centered instructional approaches more frequently also reported more SMST course elements in their courses. Post hoc comparisons indicated that respondents using lecture in every class period reported fewer SMST course elements than those who reported never using lecture, as well as those who reported using lecture weekly or several times, $F(4$, $1936)=7.16, p<.001$. Similarly, post hoc comparisons indicated that respondents who reported never using small group discussion also reported fewer SMST course elements than those who used this instructional strategy at all, including only occasionally, $F(4,1925)=19.7, p<.001$. Respondents who reported using small group interactions weekly reported the most SMST course elements in their course. Instructors who reported spending a greater percentage of class time on student activities, questions, and discussion $(r=0.132, \mathrm{n}=2033, p<.001)$ also reported incorporating more SMST course elements in their courses. Although a modest correlation, it does contribute to cumulative evidence from the survey data suggesting a positive relationship between student-centered instruction and SMST opportunities for students in geoscience courses.

In Manduca and colleagues' (2017) article analyzing results of previous administrations of the survey, the following items from Table 3 were used to identify subgroups of faculty based on factor analyses:

1. frequency of use of traditional lecture,

2. frequency of use of demonstration,

3. frequency of use of individual student questions, 


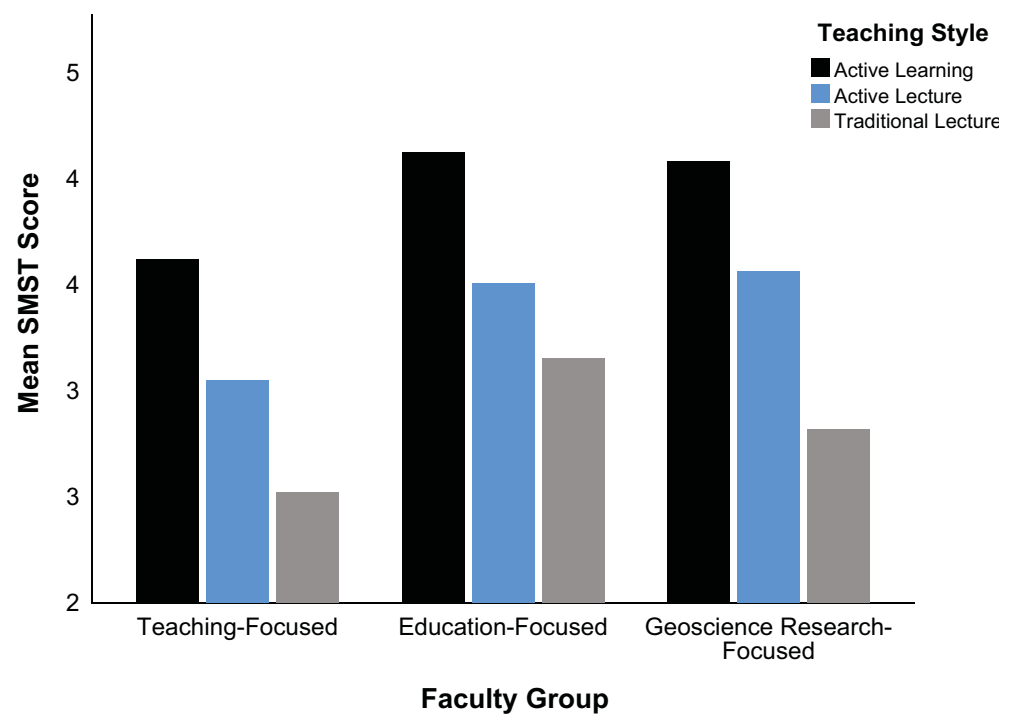

Figure 3. Composite mean SMST score for teaching style categorized by faculty types.

4. frequency of use of asking whole-class questions,

5. frequency of use of small-group discussion, and

6. frequency of use of whole-class discussion.

7. Frequency of use of in-class assignments

They identified three groups of respondents who differed in their teaching styles. These faculty groups (Manduca et al., 2017, pg. 3) were as follow:

1. Active learning: Faculty reported frequent use of small group discussion, whole-class discussion, or in-class exercises with or without the use of any other methods.

2. Active lecturing: Faculty reported frequent use of demonstrations and/or posing questions with or without traditional lecture.

3. Traditional lecturing: Faculty reported infrequent use of strategies other than traditional lecture

Consistent with Manduca and colleagues' (2017) previous study, faculty classified as active learning made up the largest percentage (60\%) of respondents, whereas those classified as traditional lecture were the smallest (11\%). Also, $29 \%$ of respondents were classified as active lecturing in the 2016 survey.

Findings show that reported SMST course elements vary by faculty teaching profiles, $F(2,1962)=38.4$, $p<.001$. Post hoc comparisons indicated that geoscience faculty characterized as active learning reported more SMST course elements than did both faculty identified as active lecturing and traditional lecturing. Additionally, faculty identified as active lecturing reported more SMST course elements than did those identified as traditional lecturing. Overall, these findings suggest that geoscience instructors who were using more active learning strategies also reported providing students more opportunities to engage in SMST, and that these opportunities increased in conjunction with the respondents' reported use of student-centered instructional strategies.

\section{A predictive model for reported SMST course elements}

The results presented thus far illustrate relational trends in the 2016 survey data for both survey respondents and the courses they taught in respect to reported SMST course elements. These results suggest that both education- and research-focused faculty using active learning strategies report including the greatest number of SMST course elements in their courses. There are few observed differences between these two groups, except for those who fall into the traditional lecturing category, for which educationfocused faculty report more SMST course elements than geoscience research-focused faculty. In contrast, teaching faculty of all types of instructional profiles report including the fewest SMST course elements. These results are summarized in Figure 3.

Given these statistically significant associations, we sought to develop a predictive model for SMST course elements in undergraduate geoscience courses. A standard multiple regression analysis was conducted to evaluate how well instructor- and course-based variables predicted respondents' reported emphasis on SMST course elements in undergraduate geoscience courses. Covariates include independent variables discussed in previous sections as associated with the 
Table 7. Results of multiple linear regression for predictors of reported SMST course elements in undergraduate geoscience courses $(n=2056)$.

\begin{tabular}{|c|c|c|c|c|c|}
\hline $\begin{array}{l}\text { Variable } \\
\text { (Constant) }\end{array}$ & $\begin{array}{l}\text { Description } \\
\text { SMST course elements }\end{array}$ & $\begin{array}{c}\beta \\
1.252\end{array}$ & $\begin{array}{l}\text { Std. Error } \\
.348\end{array}$ & $\begin{array}{c}t \\
3.601\end{array}$ & $\begin{array}{c}p \\
.000\end{array}$ \\
\hline S16_1 & $\begin{array}{l}\text { Geoscience subdiscipline of fac- } \\
\text { ulty respondent }\end{array}$ & .171 & .031 & 5.558 & .000 \\
\hline S16_25_COMP & $\begin{array}{l}\text { Number of changes made to course content } \\
\text { in past two years }\end{array}$ & .258 & .026 & 10.104 & .000 \\
\hline S16_27_COMP & $\begin{array}{l}\text { Number of changes made to teaching } \\
\text { methods in past two years }\end{array}$ & .063 & .027 & 2.343 & .019 \\
\hline PRESENTRESEARCHR & $\begin{array}{l}\text { Number of meetings presented scientific } \\
\text { research within the past two years }\end{array}$ & .049 & .030 & 1.670 & .095 \\
\hline NUMPUBLISHR & $\begin{array}{l}\text { Number of articles about research published } \\
\text { in the past two years }\end{array}$ & .069 & .025 & 2.701 & .007 \\
\hline TALKCONTENT & $\begin{array}{l}\text { Frequency of conversation with colleagues } \\
\text { about course content over the past } \\
\text { two years }\end{array}$ & .200 & .056 & 3.546 & .000 \\
\hline ATTENDTEACHTALKSR_2 & $\begin{array}{l}\text { Number of talks on teaching methods, other } \\
\text { topics related to science education, or } \\
\text { geoscience education attended in the } \\
\text { past two years at professional meetings, } \\
\text { on campus, or at other venues }\end{array}$ & .027 & .034 & .805 & .421 \\
\hline ATTENDWRKSHPR & $\begin{array}{l}\text { Number of workshops related to improving } \\
\text { teaching attended in the past two years }\end{array}$ & .010 & .041 & .254 & .800 \\
\hline PRESENTTEACH & $\begin{array}{l}\text { Number of presentations of research on } \\
\text { teaching methods or student learning at } \\
\text { meetings within the past two years }\end{array}$ & .372 & .126 & 2.950 & .003 \\
\hline NUMARTICLES & $\begin{array}{l}\text { Number of articles published about educa- } \\
\text { tional topics within the past two years }\end{array}$ & -.020 & .083 & -.245 & .807 \\
\hline TRADLECb & Frequency of use of traditional lecture & -.088 & .120 & -.726 & .468 \\
\hline LECDEMOb & Frequency of use of demonstration & .125 & .102 & 1.224 & .221 \\
\hline INDIVQUESTb & $\begin{array}{l}\text { Frequency of use of individual stu- } \\
\text { dent questions }\end{array}$ & .252 & .100 & 2.519 & .012 \\
\hline ALLQUESTb & $\begin{array}{l}\text { Frequency of use of asking whole- } \\
\text { class questions }\end{array}$ & -.119 & .111 & -1.070 & .285 \\
\hline SMALLGRPDISb & Frequency of use of small-group discussion & .237 & .121 & 1.949 & .051 \\
\hline WHOLEGRPDISb & Frequency of use of whole-class discussion & .441 & .110 & 3.993 & .000 \\
\hline INCLASSb & Frequency of use of in-class assignments & .021 & .109 & .194 & .846 \\
\hline
\end{tabular}

outcome variable of interest (SMST course elements), including respondents' subdiscipline, and number of changes to both course content and teaching methods, and those that comprised categories for both faculty type and teaching style identified in Manduca and colleagues' (2017) study. Of the 17 predictor variables included in the regression model, 10 had a significant $(p<.01)$ zero-order correlation with SMST and significant $(p<.05)$ partial effects in the full model. A zero-order correlation means there were no control variables among SMST and the 17 predictor variables. Partial effects are the statistical result of holding one variable constant to determine if it is a potential cause of correlation between other components. The estimated intercept for SMST course elements $(\beta=$ 1.252 ) indicates the expected number of SMST course elements for a survey respondent with average scores on these 17 predictor variables. The model was able to account for $17 \%$ of the variance in reported SMST course elements, $F(9,2010)=21.12, p=.007, R^{2}=$ $.17,95 \%$ CI $[.69,2.3]$. The results of the regression are presented in Table 7 and in Appendix B.

The model illustrates the predictive power of variables already identified in these analyses as associated with reported SMST course elements. Variables that were most strongly predictive of SMST course elements revolve directly around reporting and implementation of classroom instruction. These include respondents' presentations of research on geoscience teaching and learning (10\%), as well as reported instructional practices, such as student questions (8\%) and the use of small-group (10\%) and whole-class (9\%) discussion. Collectively, a 1-unit increase to each of these variables resulted in a 1.23-unit increase in reported SMST scores, highlighting the particular importance of these variables underlying both faculty type and instructional style profiles. Other variablessuch as geoscience subdiscipline (2.5\%), number of changes to course content (2\%) and teaching (2\%), and frequencies of conversations with colleagues about teaching $(4.5 \%)$-were also shown to be statistically significant predictors of reported SMST course elements, but to a lesser degree. However, not all variables that comprised the faculty type and instructional style profiles were shown to predict reported SMST course elements. Presentations of research at conferences, attendance at teaching presentations or workshops, and publishing articles on teaching methods 
were not observed to predict reported SMST course elements. More teacher-centered instructional approaches-such as lecture, demonstration, and instructor questioning-were also not observed to predict reported SMST course elements. Overall, results from this model provide a profile of geoscience faculty using research-based teaching methods in their courses and actively disseminating their work to colleagues as most predictive of emphasizing SMST in their undergraduate courses.

\section{Summary of results}

Overall, results illustrate average levels of SMST course elements reported by geoscience faculty members teaching undergraduate geoscience courses, as well as which are most commonly emphasized and by whom. Respondents who are actively revising the content and teaching in their courses, attending workshops and presentations on effective instruction, reading geoscience education research, and using more reform-based instructional strategies in their classrooms generally report a stronger emphasis on SMST practices in their courses. These trends are slightly stronger in courses for geoscience majors and are consistent for both education- and researchfocused faculty members, particularly in geoscience subdisciplines of atmospheric science, meteorology, environmental sciences, and hydrology. Collectively, these factors help account for less than $20 \%$ of the variation expected in reported SMST practices emphasized by geoscience faculty teaching undergraduate geoscience courses, suggesting that one or more other factors are responsible for the remaining differences in SMST in undergraduate geoscience courses.

\section{Discussion}

Introductory STEM courses are often the last opportunity for K-16 students to learn universally beneficial skills, such as engaging in evidence-based scientific reasoning and learning to think scientifically (Somerville \& Bishop, 1997; Tewksbury et al., 2013), in formal classroom settings. Consequently, there has been a growing recognition of the need for STEM faculty to not only conduct research in their disciplines but also deliver high quality education (NRC, 2012), particularly in the geosciences (Somerville \& Bishop, 1997). To address this need, more geoscience faculty members than ever before are taking advantage of professional development opportunities (Manduca et al., 2017). All types of faculty-education-, research-, and teaching-focused-are increasingly attending teaching seminars and workshops to enhance their instruction (Manduca et al., 2017). Encouragingly, many undergraduate students do experience some SMST (Forbes et al., 2018; Gunn, Mohtar, \& Engel, 2002; McNeal, Miller, \& Herbert, 2008; Williams, Lansey, \& Washburne, 2009), but introductory geoscience courses do not tend to incorporate SMST; instead, students receive exposure to SMST in other courses (Macdonald et al., 2005). SMST skills encourage students to think about relationships between interacting components and the ability to demonstrate what those components and interactions look like (Baumfalk et al., in press; Bawden et al., 1984; Danish, et al., 2017; Schwarz et al., 2009; Troy et al., 2015). However, despite these advancements made in faculty preparation and student learning, gaps remain in what we know about effective teaching and learning in undergraduate geoscience courses. More work is needed to identify the highest impact strategies for student learning, how to support faculty to engage in instructional change, and identification of institutional features that foster both (Libarkin \& Anderson, 2005; Macdonald et al., 2005, Zigic \& Lemckert, 2007). Results from this study provide important insights into the current use and emphasis on one set of related learning processes and outcomes--SMST-in postsecondary geoscience courses that can optimally meet the needs of the STEM workforce and cultivate scientifically literate citizens.

First, study results provide insight into SMST in undergraduate geoscience courses. The most frequently used SMST elements are the discussions of a change with multiple effects in the system, the complexity of scale and interactions, and the description of a system in terms of parts and relationships. These three elements are found in over half of the courses taught by instructors responding to the survey in this study. This implies that over half of the students in these courses are being afforded opportunities to increase their familiarity with the interconnectedness of systems and the different ways changes are observed in varying system components. Alternately, the practices of making systems visible through causal maps, system exploration using computer-based models, and the building of predictive models are the least common in courses. Student learning is enhanced with the inclusion of multiple types and opportunities for modeling and systems thinking (Arnold \& Wade, 2015; Assaraf \& Orion, 2005; Baumfalk et al., in press; Hmelo-Silver, et al., 2017; Scherer, Holder, \& Herbert, 2017; Williams, Lansey, \& Washburne, 2009). An emphasis on SMST in geoscience courses is a critical 
way to cultivate a scientifically literate populous (Mosher et al., 2014) and respond to calls from government agencies and policy documents (Earth Science Literacy Initiative, 2010; U.S. Department of Energy, 2012; U.S. Global Change Research Program, 2009). However, although many argue for the importance of SMST in undergraduate STEM education, including the geosciences, and disciplinary standards for geoscience teaching and learning exist, there is less guidance on targets for the extent to which SMST should specifically be emphasized in particular disciplinary contexts. Without clearly articulated benchmarks for STEM practices, including SMST and particularly at the undergraduate level, it is difficult for both educators and researchers to make judgments about the implementation of SMST in undergraduate geoscience courses. As such, more work is needed to provide an empirical basis for both defining objective outcomes and measuring progress toward SMSTrelated goals for undergraduate teaching and learning.

Second, differences were observed in reported SMST practices between instructors in the geoscience subdisciplines. Faculty associated with meteorology, climate science, environmental science, and "other" subdisciplines reported the highest rates of SMST practices, whereas geology instructors reported the fewest SMST practices. One interpretation of this finding is that meteorology and climate science lend themselves more readily to SMST than do other subdisciplines in the geosciences. Modeling in these courses is critical because the phenomena under study may be difficult to observe in real life, necessitating modeling so that the unseen can become seen. Another possible explanation is the temporal foci of these disciplines. Whereas traditional geology is largely concerned with views into Earth's past, much of contemporary meteorology, climate science, and environmental science is concerned with evidencebased predictions of the future, which involves the use of big data and complex models. As such, faculty in various subdisciplines may vary in the ways they are prepared to teach and in the opportunities afforded to tenure-track faculty who are new to supporting student learning about SMST (Libarkin, 2006). However, these differences in the particulars of SMST inclusion and practice are not necessarily negative; the added diversity might be beneficial for student learning. More research would help illuminate the ways in which particular SMST practices are implemented in undergraduate geoscience courses spanning these subdisciplines.

Third, results illustrate how SMST practices are being emphasized to varying degrees by different groups of geoscience faculty. Education- and research- focused faculty both report implementing more SMST practices than teaching-focused faculty. Conventional wisdom might suggest that these two groups would not overlap in their teaching strategies. Surprisingly, there is a fair amount of relatability between them, with research faculty reporting using SMST practices at a similar level as the education-focused faculty within the geosciences. Despite roadblocks such as lack of knowledge of professional development opportunities, the number of faculty in the United States incorporating SMST is on the rise (Mosher et al., 2014). Even though research and education faculty appear distinct, they likely share important similarities. For example, these two groups are likely teaching similar populations of undergraduate students and similar types and quantities of courses (Manduca et al., 2017). Even though some groups within the geosciences are using SMST and providing students similar types of student-centered experiences, this is not the case across all instructors. Not all types of geoscience faculty reported employing SMST practices to the same extent. Disaggregating faculty by groupsteaching faculty, research focused, and education focused-revealed the clear trend that the teachingfocused instructors are emphasizing SMST practices the least. Teaching-focused instructors may avoid SMST because they teach too many courses, have little or no access to resources to help them incorporate SMST practices, and their courses may be more challenging from an instructional standpoint, so they use lecture most often as supported by the results.

Fourth, in addition to faculty type, instructional profiles of respondents also illuminate differences in reported SMST practices in geoscience classrooms. The instructors reporting the use of more active learning strategies in their courses also reported more SMST practices. Lecture is still used in a number of classes and is an important teaching strategy. However, lecture does have drawbacks, including limited student involvement and opportunities for critical thinking (Macdonald et al., 2005). Active learning is integral to incorporate in geoscience classrooms, often taking the form of SMST, consistent with broader calls for undergraduate education in STEM (NRC, 2002). SMST practices encompass active learning components, including group discussions, evaluation of understanding, and actively engaging the student in doing the associated activities. The educators reporting increased active learning in their classroom are incorporating best practice strategies. Based on study results, we would also observe that courses with less active learning would necessarily exhibit less SMST, 
resultantly. As recently as the 2012 implementation of the National Geoscience Faculty Survey, $49 \%$ of instructors were implementing lecture for $80 \%$ of course time (Manduca et al., 2017). The accomplishment of converting time from lecture to SMST and other student-centered teaching strategies is a worthwhile investment in terms of student participation and learning (McNeal, Miller, \& Herbert, 2008; Mosher, et al., 2014). Making the shift from lecture to studentcentered instruction is important to meeting the goal of high-quality teaching and meaningful learning (Manduca, et al., 2017), including SMST.

Finally, results from the regression model highlight the predictive capabilities of these variables. Although variables measured in the survey and discussed here have the ability to predict nearly $20 \%$ of the overall variability in reported SMST practices in undergraduate geoscience classrooms, this leaves over $80 \%$ of the variability unexplained. The remaining variability may be related to SMST through factors that were not captured by the survey. Variables such as perceived student benefits, the difficulty of grading SMST assignments, priorities of individual institutions, and available instructional technology and support could all affect the implementation of SMST in undergraduate geoscience courses. Instructors who do not understand the benefits of SMST to student learning might not include these practices as often in their courses. SMST assignments can be lengthy and difficult to grade because of the individualized interpretations and solutions presented by students. The amount of time it takes to grade such assessments in large-enrollment courses may be cost prohibitive. Support of interdisciplinary course components may not be available within all disciplines. Instructors who do not feel supported in these efforts may not feel compelled to include content outside of their area of expertise. Many of these variables could be influenced by other processes and components. More research is needed to explore other factors that may predict how and to what extend SMST practices are implemented in undergraduate geoscience courses.

\section{Limitations}

Limitations inherent to this study may affect the unexplained variability found in the type of SMST practices reported by instructors in geoscience classrooms. For example, the GER survey is self-report. There are no additional interviews or other qualitative data to clarify responses or provide examples. As a result, conclusions drawn from analysis of survey data are uncorroborated. Correspondingly, the response rate for the survey was low. Out of 10, 910 individuals contacted for survey completion, only 2,615 responses meeting required criteria for inclusion were returned. Criteria for inclusion included being current instructor and submission of a valid email address. The response rate of $27.3 \%$ indicates that the SMST practices of nearly two-thirds of geoscience instructors are not included in the data. Another limitation unrelated to the survey is the reality that there may be more than nine elements of SMST. This survey captured data on the nine items that are known to contribute to SMST, but there could be others that are missing. This would result in an incomplete picture of SMST practices in postsecondary geoscience classrooms.

\section{Implications and conclusion}

The emphasis on SMST practices in undergraduate geoscience courses is important to the overarching goal of enhancing undergraduate STEM teaching and learning. Opportunities for SMST are needed to support undergraduate students' learning about Earth systems. However, this type of change does not happen in a vacuum. Sustained support from administration and constant evaluation of teaching efforts by individual faculty are critical to the incorporation of more SMST practices in the geosciences (Mosher et al., 2014). When the fewest opportunities are afforded in the most common courses, such as introductory geology, this is a point of concern. This constitutes both the largest group of students and instructors and the lowest frequency of reported SMST practices. We must continue to identify and advocate ways to incorporate SMST into these high-enrollment introductory courses, which reach many students and arguably have the greatest impact on fostering scientific literacy.

Financial and pedagogical support for teaching, research-focused and education-focused faculty, as well as graduate students and two-year college faculty are needed to enable the systemic changes needed in SMST instruction (Mosher et al., 2014). Different approaches for different types of instructors is appropriate given the resources available to them. Not only are differences and similarities between instructor type important to consider, differences between geoscience subdisciplines also factor into the implementation of SMST practices. SMST occurs less in traditional, instructor-centered, lecture-style classrooms than in student-centered classrooms in which active learning strategies are employed. As such, more attention is 
needed to developing strategies to address SMST teaching and learning practices in these types of settings. Providing opportunities to faculty to learn course-specific SMST strategies would be beneficial for students and instructors.

There are also relationships between variables reflecting individual faculty involvement in pedagogyfocused professional development. As shown in the study findings, the more involved an instructor is in an array of professional development activities, the more SMST he or she reports. This points to the possibility that the more involvement in and the more discourse about teaching an instructor has, the more likely SMST will be incorporated into his or her classes. Different types of faculty, in terms of both content area and faculty type, need to work together to enhance student learning, because each group brings a different skillset to the classroom (Kastens et al., 2009; NRC, 2012,). Future research is needed, including observational studies, to validate and examine the relationship between teaching-focused professional development and SMST incorporation. Regardless of the direct cause, it is beneficial for faculty to participate in these types of pedagogical activities (Manduca, et al., 2017; National Research Council, 2012). Active participation in the overarching geoscience education discussion, science-based teaching methods, and SMST-a leading component of geoscience education-will help hasten the pace of necessary course changes, including content and teaching approaches.

\section{Acknowledgments}

The authors conceptualized this study, conducted data analyses, and authored the manuscript. We acknowledge and thank the following individuals for other contributions, which made this study possible: Raymond Y. Chu, Julius Dollison, and Roman Czujko of the Statistical Research Center of the American Institute of Physics helped develop the 2004 and 2009 survey instruments, administer these surveys, and did the initial analysis of the results. Diane EbertMay and colleagues in biology provided an unpublished copy of a similar survey developed for biology from which the 2004 leadership team benefited. Staff, including Nick Claudy and Christopher Keane, from the American Geological Institute worked through permissions to provide the initial set of geoscience faculty email addresses. John McLaughlin, the On the Cutting Edge external evaluator, made contributions to the development of the 2004 and 2009 survey instruments. Experts from Professional Data Analysts, Inc.-including Michael Luxenberg, Becky Lien, Eric Graalum, and Mao Thao-worked on the analysis of the 2009 survey and development and analysis of the 2012 and 2016 survey. Lija Greenseid, of Greenseid Consulting Group, LLC, facilitated survey design and implementation and contributed to interpretation of data analysis (2012 and 2016). Thank you to On the Cutting Edge PIs: R. Heather Macdonald, Cathryn A. Manduca, David W. Mogk, Barbara J. Tewksbury, Rachel Beane, David McConnell, Katryn Wiese, and Michael Wysession.

\section{Funding}

This work was supported by the National Science Foundation's Division of Undergraduate Education (DUE) under awards 0127310, 0127141, 0127257, 0127018, 0618482, 0618725, 0618533, 1022680, 1022776, 1022844 $1022910,1125331,1525593,1524605,1524623,1524800$ and 1609598. Any opinions, findings, and conclusions or recommendations expressed in this material are those of the authors and do not necessarily reflect the views of the National Science Foundation.

\section{ORCID}

Cory T. Forbes (D) http://orcid.org/0000-0003-2230-4251

\section{References}

Arnold, R. D., \& Wade, J. P. (2015). A definition of systems thinking: A systems approach. Procedia Computer Science, 44, 669-678. doi:10.1016/j.procs.2015.03.050

Assaraf, O.B.Z., \& Orion, N. (2005). Development of systems thinking skills in the context of earth system education. Journal of Research in Science Teaching, 42(5), 518-560. doi:10.1002/tea.20061

Baumfalk, B., Bhattacharya, D., Vo, T., Forbes, C., Zangori, L., \& Schwarz, C. (2018). Impact of model-based curriculum and instruction on elementary students' explanations for the hydrosphere. Journal of Research in Science Teaching. Advance online publication. doi:10.1002/ tea. 21514

Bawden, R. J., Macadam, R. D., Packham, R. J., \& Valentine, I. (1984). Systems thinking and practices in the education of agriculturalists. Agricultural systems, 13(4), 205-225. doi:10.1016/0308-521X(84)90074-X

Danish, J., Saleh, A., Andrade, A., \& Bryan, B. (2017). Observing complex systems thinking in the zone of proximal development. Instructional Science, 45(1), 5-24. doi: 10.1007/s11251-016-9391-z

Earth Science Literacy Initiative. (2010). Earth science literacy principles: The big ideas and supporting concepts of Earth science. Arlington, VA: National Science Foundation.

Forbes, C.T., Brozovic, N., Franz, T., Lally, D., \& Petitt, D. (2018). Water in Society: An interdisciplinary course to support undergraduate students' water literacy. Journal of College Science Teaching, 48(1), 36-42.

Gunn, R. L., Mohtar, R. H., \& Engel, B. A. (2002). WorldWide-Web-based soil and water quality modeling in undergraduate education. Journal of Natural Resources and Life Sciences Education, 31, 141-147. 
Hmelo-Silver, C. E., Jordan, R., Eberbach, C., \& Sinha, S. (2017). Systems learning with a conceptual representation: A quasi-experimental study. Instructional Science, 45(1), 53-72. doi:10.1007/s11251-016-9392-y

Kastens, K. A., Manduca, C. A., Cervato, C., Frodeman, R., Goodwin, C., Liben, L. S., \& Titus, S. (2009). How geoscientists think and learn. Eos, Transactions American Geophysical Union, 90(31), 265-266. doi:10.1029/ 2009EO310001

Libarkin, J. C. (2006). Geoscience education in the United States. Planet, 17(1), 60-63. doi:10.11120/plan.2006. 00170060

Libarkin, J. C., \& Anderson, S. W. (2005). Assessment of learning in entry-level geoscience courses: Results from the geoscience concept inventory. Journal of Geoscience Education, 53(4), 394-401. doi:10.5408/1089-9995-53.4.394

Macdonald, H.R., Manduca, C.A., Mogk, D.W., and Tewksbury, B.J. (2005) Teaching methods in undergraduate geoscience courses: Results of the 2004 on the cutting edge survey of U.S. faculty. Journal of Geoscience Education, 53(3), 237-252. doi:10.5408/1089-9995-53.3.237

Manduca, C. A., Iverson, E. R., Luxenberg, M., Macdonald, R. H., McConnell, D. A., Mogk, D. W., \& Tewksbury, B. J. (2017). Improving undergraduate STEM education: The efficacy of discipline-based professional development. Science Advances, 3(2), e1600193. doi:10.1126/sciadv. 1600193

McNeal, K. S., Miller, H. R., \& Herbert, B. E. (2008). The effect of using inquiry and multiple representations on introductory geology students' conceptual model development of coastal eutrophication. Journal of Geoscience Education, 56(3), 201-211. doi:10.5408/1089-9995-56.3.201

Mosher, S., Bralower, T., Huntoon, J., Lea, P., McConnell, D., Miller, K., Ryan, J., Summa, L., Villalobos, J., \& White, L. (2014). Future of undergraduate geoscience education: Summary report for summit on future of undergraduate geoscience education.

National Research Council. (2012). Discipline-based education research: Understanding and improving learning in undergraduate science and engineering. National Academies Press.

Scherer, H.H., Holder, L., \& Herbert, B.E. (2017) Student learning of complex Earth systems: Conceptual frameworks of Earth systems and instructional design. Journal of Geoscience Education, 65(4), 473-489.

Schwarz, C. V., Reiser, B. J., Davis, E. A., Kenyon, L., Achér, A., Fortus, D., ... \& Krajcik, J. (2009). Developing a learning progression for scientific modeling: Making scientific modeling accessible and meaningful for learners. Journal of research in science teaching, 46(6), 632-654. doi:10.1002/tea.20311

Somerville, R., \& Bishop, W. (1997). Geoscience education: A recommended strategy. National Science Foundation, NSF, 97-171.

Tewksbury, B. J., Manduca, C. A., Mogk, D. W., Macdonald, R. H., \& Bickford, M. E. (2013). Geoscience education for the Anthropocene. Geological Society of America Special Papers, 501, 189-201.

Troy, T. J., Konar, M., Srinivasan, V., \& Thompson, S. (2015). Moving sociohydrology forward: A synthesis across studies. Hydrology and Earth System Sciences, 19(8), 3667-3679. doi:10.5194/hess-19-3667-2015
U.S. Department of Energy. (2012). Essential principles and fundamental concepts for energy education.

U.S. Global Change Research Program. (2009). Climate literacy: The essential principles of climate science.

Williams, A., Lansey, K., \& Washburne, J. (2009). A dynamic simulation based water resources education tool. Journal of Environmental Management, 90(1), 471-482. doi:10.1016/j.jenvman.2007.11.005

Zigic, S., \& Lemckert, C. J. (2007). Development of an interactive computer-based learning strategy to assist in teaching water quality modelling. Computers \& Education, 49(4), 1246-1257.

\section{Appendix A.}

\begin{tabular}{lrr}
\hline Respondent institution types. & & \\
\hline & $N$ & $\%$ \\
\hline Research/doctoral & 1466 & $59.5 \%$ \\
Master's & 440 & $17.9 \%$ \\
Baccalaureate & 232 & $9.4 \%$ \\
Associate's & 316 & $12.8 \%$ \\
Special focus/Other & 8 & $.3 \%$ \\
Total $(n)$ & 2462 & $100.0 \%$ \\
Missing & 153 & \\
\hline
\end{tabular}

\begin{tabular}{lccc}
\hline Response rate & & & \\
\hline Institution type & Respondents & Total sampled & Response rate \\
\hline Research and/or doctoral & 1466 & 6512 & $22.5 \%$ \\
Master's, baccalaureate, & 996 & 3566 & $27.9 \%$ \\
associate, or other & & & \\
institution types & & & \\
\hline
\end{tabular}

\begin{tabular}{lcc}
\hline Level of education & & \\
\hline & $n$ & $\%$ \\
\hline Master's & 284 & $11 \%$ \\
Ph.D. & 2285 & $89 \%$ \\
\hline
\end{tabular}

Note: Not all respondents reported this variable.

\begin{tabular}{lcc}
\hline $\begin{array}{l}\text { Years in position } \\
\text { Years }\end{array}$ & $n$ & $\%$ \\
\hline $0-5$ & 436 & $17.1 \%$ \\
$6-10$ & 444 & $17.4 \%$ \\
$11-15$ & 398 & $15.6 \%$ \\
$16-20$ & 374 & $14.6 \%$ \\
$21-25$ & 283 & $11.1 \%$ \\
$26-30$ & 245 & $9.6 \%$ \\
$31-35$ & 178 & $7 \%$ \\
$36-40$ & 123 & $4.9 \%$ \\
$41-45$ & 66 & $2.6 \%$ \\
\hline
\end{tabular}

Note: Not all respondents reported this variable.

\begin{tabular}{lcr}
\hline Disciplinary focus & & \\
\hline & $n$ & $\%$ \\
\hline Oceanography & 241 & $9.3 \%$ \\
Atmospheric science & 247 & $9.5 \%$ \\
Geology/other & 2,112 & $81.2 \%$ \\
Total & 2,600 & $100.0 \%$ \\
\hline
\end{tabular}

Note: Not all respondents reported this variable. 


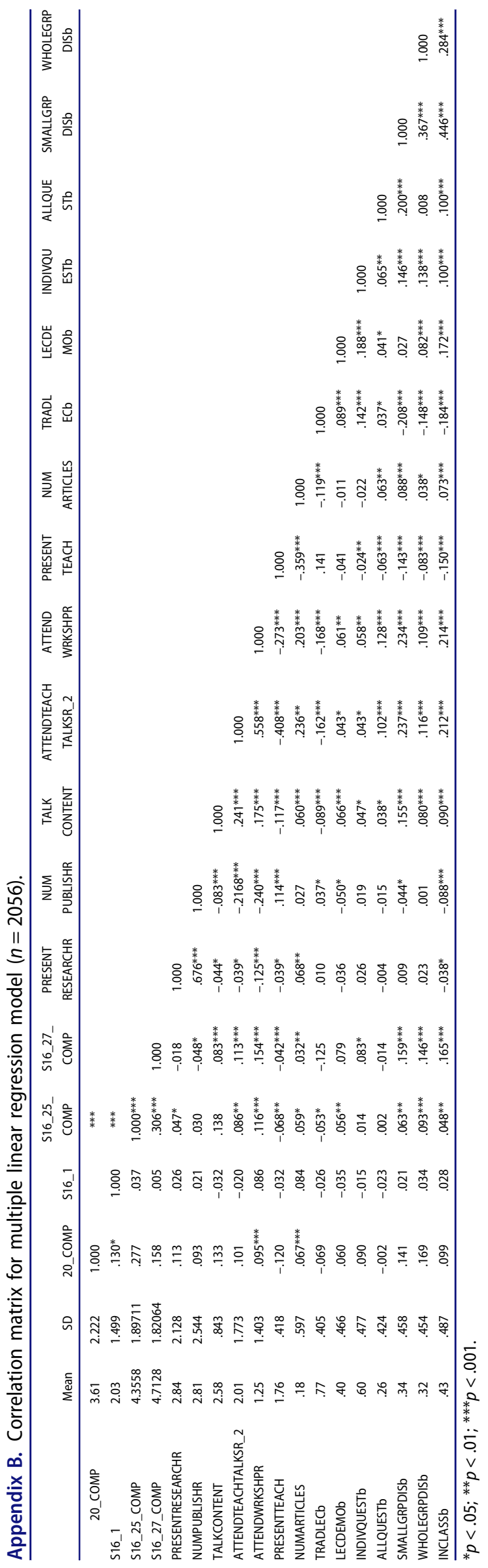

